\title{
Proposal of Strength Formula and Type Development of Composite Mega Column to Beam Connections with T-shaped Stiffener
}

\author{
Jae-Hyun Lee ${ }^{a}$, Sun-Hee Kima, Bu-Kyu Kimb, Kyong-Soo Yom ${ }^{\mathrm{c}}$ and Sung-Mo Choi ${ }^{\mathrm{a}}$ * \\ ${ }^{a}$ Department of Architectural Engineering, University of Seoul, Korea \\ ${ }^{\mathrm{b}}$ Suhhan Architects and Engineers inc., Seoul, Korea \\ c Act Partner, Seoul, Korea \\ *corresponding author, e-mail address: smc@uos.ac.kr
}

\begin{abstract}
As buildings are becoming larger, demand for mega-sized composite columns (over 1meter diameter) is increased. We have developed and commercialized welded built-up CFT column (ACT Column I) since 2005 which are structurally stable and economical using cold-formed steel with rib. However, there has a limit in size of cross section (618 X $618 \mathrm{~mm}$ ) by a fabrication facilities. And due to charateristics of closed cross section, there has a limit to construction of connection of moment frame. Composite mega column (ACT Column II) has same concept of forming closed cross section. But in order to enlarge cross sectional size, thick plate is inserted between cold-formed steels. Since composite mega column can control thickness and width of thick plate, steel or composite beams can be directly attached to the connection. In this study, we propose strength formula of composite mega column to beam connections with T-shaped stiffener as internal diaphragm and verified through finite element analysis and simple tensile experiment.
\end{abstract}

Keywords: Welded built-up CFT column; Composite mega column; T-shaped Stiffener;

Tensile strength formula

\section{Introduction}

\subsection{Background and purpose of study}

Due to development of IT / logistics industry, internet transactions have risen and buildings have become larger for logistics storage and delivery. As a result, demand for large-sized composite columns for heavy loads also increased. In previous study, we have developed stable and economical welded built-up CFT column (ACT Column I) using cold-formed steel with rib. However, there has a limit in size of cross section $(618 \mathrm{~mm} \times 618 \mathrm{~mm})$. And it is difficult to select inner diaphragm and through diaphragm because continuity of rib must be secured in order to demonstrate structural performance as a column. In addition, due to charateristics of closed cross section, there has a limit to construction of connection for moment frame. Fig. 1 (a) shows shape of welded built-up CFT Column.[1]

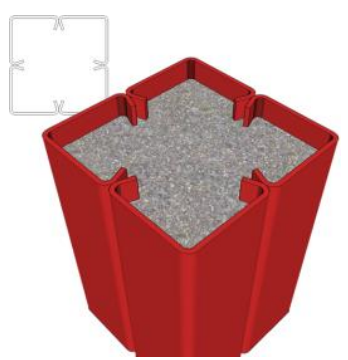

(a)Welded buit-up CFT column

Fig. 1. Shape of ACT Column

Then, in order to solve problems of welded built-up CFT column, composite mega column (ACT Column II) was developed while maintaining advantages of welded built-up column. Composite mega column has a closed cross section like welded built-up column, but thick plate is inserted between cold-formed steel to expand cross section size. Fig. 1 (b) shows shape of composite mega column. And because 
stiffener can be pre-assembled to thick plate, there is an advantage that detail of connection is simplified. In addition, thickness and width of thick plate can be adjusted, steel or composite beams can be directly attached to the connection. Fig. 2 shows basic concept of composite mega column forming process.

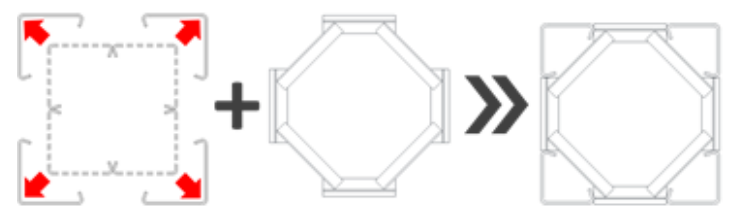

Fig. 2. Basic concept of composite mega column

However, despite structural strength of composite mega column, charactertistic of closed cross section make it difficult to reinforce connection and complicate construction of connection. Therefore, it is necessary to develop and study connection type that can secure strength of connection and take into consideration workability and economy. Currently, commonly used types of connections are classified into three types as shown in Fig. 3: through diaphragm, internal diaphragm, and external diaphragm.
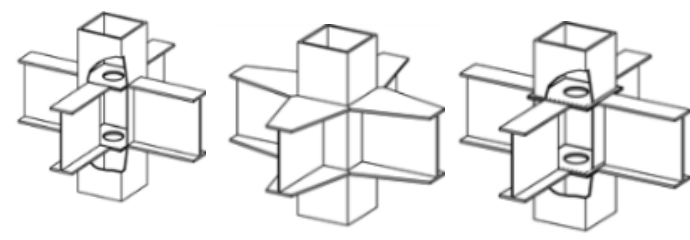

(a)internal diaphragm

\begin{abstract}
(b)external diaphragm
\end{abstract}

\begin{abstract}
(c)through diaphragm
\end{abstract}

Fig. 3.CFT column to beam connection type

External diaphragm was applied to welded built-up CFT column to secure continuity of rib. However, if external diaphragm is applied to composite mega column with a width of $1 \mathrm{~m}$ or more, amount of steel increases greatly and interference with finishing material occurs. Therefore, in this study, connection type is set as internal diaphragm, we will develop connection shape and propose strength formula.

\section{Connection type of inner diaphragm}

Composite mega column were applied to internal diaphragm connection to overcome problems of external diaphragm. In previous study, internal diaphragm is divided into two types, horizontal stiffener and T-shaped stiffener.
Shape of each internal diaphragm is shown in Fig. 4.[2]

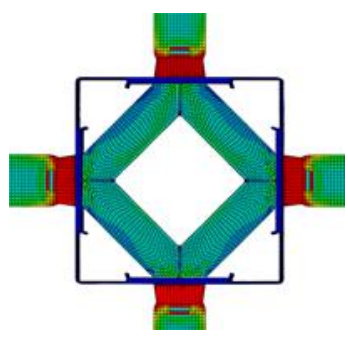

(a)T-shaped stiffener

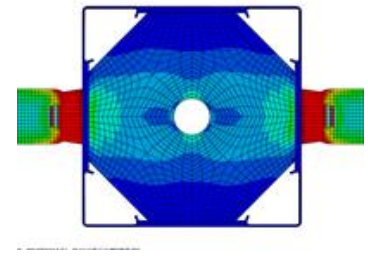

(b)Horizontal stiffener
Fig. 4.Application shape of internal diaphragm

T-shaped stiffener is composed of two members, vertical member and horizontal member. In composite mega column, vertical member acts as anchor to induce concrete cone failure. Further, load transfer can be clarified through horizontal member. Horizontal stiffener is internal diaphragm having only a horizontal member, and larger amount of steel is used than T-shaped stiffener. Based on these characteristics, it is considered that T-shaped stiffener is effective diaphragm shape as compared with horizontal stiffener and is suitable for composite mega column. Therefore, we propose a strength formula of composite mega column connection with T-shaped stiffener.

\subsection{Details of T-shaped stiffener}

When beam flange is subjected to tensile force, T-shaped stiffener welded to inner surface of column transmits tensile force on opposite side with deformation. As shown in Fig. 5, Tshaped stiffener is divided into vertical member and horizontal member. Horizontal member determines size of cross section to resist tensile force, and vertical member determines height of concrete cone.
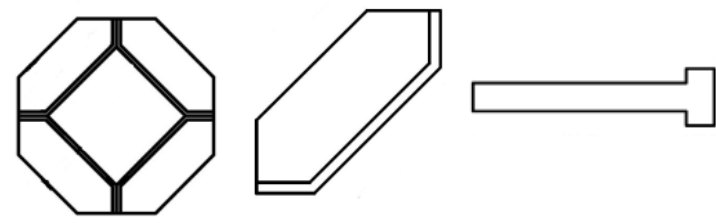

Fig. 5. Details of T-shaped stiffener

\section{Proposal of composite mega column connection strength formula}

Load resistance mechanism for each model is as follows. In case of concrete non-charging model, it is assumed that out-of-plane 
deformation of steel pipe and yield strength of $\mathrm{T}$ shaped stiffener resist load. In case of concrete charging model, since concrete controls out-ofplane deformation of steel pipe, it is assumed that it is resistant to load by concrete cone failure and yield strength of T-shaped stiffener.

\subsection{Limitations for strength formula proposal}

(1) Maximum strength of weld zone shall be greater than maximum strength of non-charging or charging steel pipe.

(2) Strength of proposed formula should be greater than beam flange tensile strength.

(3) In case of concrete charging model, it is assumed that tensile force transferred from beam flange is transferred to concrete cone and $\mathrm{T}$ shaped stiffener.

\section{2. $T$-shaped stiffener yield strength formula}

Cross-sectional size of T-shaped stiffener can be expressed as Eq. (1). Yield strength of Tshaped stiffener is assumed to be tensile at all of cross sections. And as can be seen from the arrow in Fig. 6, tensile force transferred from flange acts as angle of $\theta$. Yield strength formula of T-shaped stiffener is shown in Eq. (2).

Tshaped Stiffener Cross sectional size

$$
\begin{aligned}
& =b_{s} \times h_{s} \times t_{s h} \times t_{s v} \\
P_{s} & =b_{s} \times t_{s h} \times f_{y s} \times 2 \times \cos \theta
\end{aligned}
$$

$b_{s}$ : Width of horizontal member

$h_{s}:$ Height of vertical member

$t_{s h}$ : Thickness of horizontal member

$t_{s v}$ : Thickness of vertical member

$f_{y s}$ : Yield strength of T-shaped stiffener

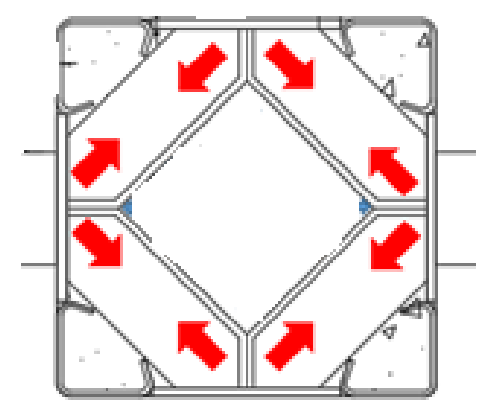

Fig. 6. Tensile force transfer in T-shaped stiffener

\subsection{Concrete cone failure strength formula}

Concrete cone failure resulting from tensile force transferred from $\mathrm{T}$-shaped stiffener vertical member is based on assumption that cone failure occurs in 45 degree direction. Cone failure is assumed to occur simultaneously with deformation of T-shaped stiffener. Area of cone failure consists of area surrounded by line connecting column-side end of $\mathrm{T}$-shaped stiffener to end of T-shaped stiffener vertical member.

(1) Cone failure area in column section

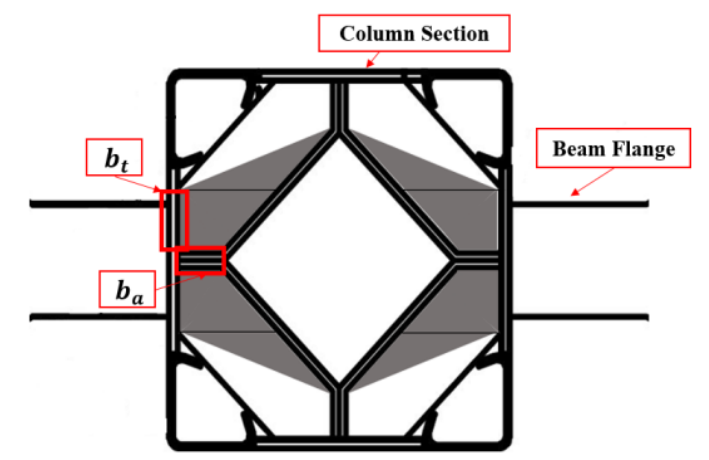

Fig. 7.Cone failure in column section

Concrete Cone failure area in column section is shown in Fig. 7. This area is assumed to be area surrounded by line connectiong columnside end of T-shaped stiffener to end of T-shaped stiffener vertical member. Strength formula for concrete cone failure in column section is shown in Eq. (3).

$$
\begin{aligned}
P_{c 1}= & 2 \times\left[\left(\left(\sqrt{2} b_{s}+b_{a}\right) \times b_{t}\right)+\left(\sqrt{2} b_{s} \times\right.\right. \\
& \left.\left.\left(\frac{b_{c}}{2}-t_{s v}-b_{a}-b_{t}\right)\right)\right] \times v_{c}
\end{aligned}
$$

$b_{a}$ : Length of rib / $b_{c}$ : Width of concrete

$b_{t}$ : Width of T-shaped stiffener attached to thick plate

$v_{c}$ : Shear strength of concrete

(2) Cone failure area at front of column

Cone failure area at front of column is area generated at 45 degree from end of T-shaped stiffener vertical member as shown in Fig. 8. Strength formula for concrete cone failure at front of column is shown in Eq. (4).

$P_{c 2}=2 f_{t}\left(h_{c}+h_{s}-2 t_{s h}\right) \times\left(\frac{b_{c}}{2}-t_{s v}\right)$

$h_{c}$ : Height of concrete cone 
$f_{t}:$ Tensile strength of concrete
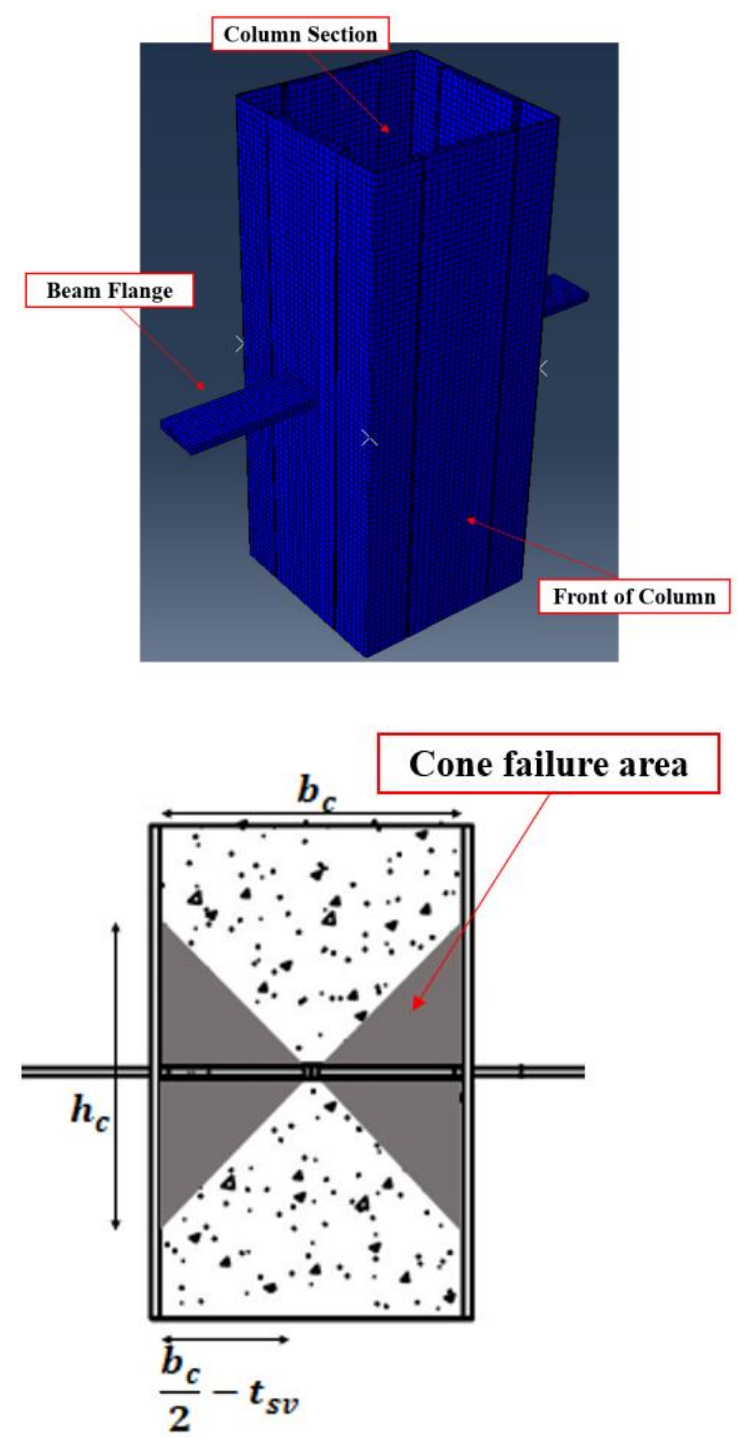

Fig. 8.Cone failure at front of column

\section{Finite element analysis for T-shaped stiffener yield strength formula verification}

\subsection{Analysis overview}

For verification of proposed strength formula, finite element analysis was performed using Abaqus 6.13. Analysis was carried out on simple tensile connection with beam flange (PL$300 \times 55 \mathrm{~mm}$ ) attached to steel pipe of $1200 \times 1200 \times 3000 \mathrm{~mm}$ in size. Analysis used solid element and boundary conditions were fixed at $\mathrm{U} 1, \mathrm{U} 2, \mathrm{U} 3=0$ on one flange and $500 \mathrm{~mm}$ displacement control on $\mathrm{U} 1$ at the end of opposite flange. Yield strength of applied material is $325 \mathrm{MPa}$ and modulus of elasticity is $205 \mathrm{GPa}$. Loading was performed by $500 \mathrm{~mm}$ displacement control and strength was evaluated by reaction force of flange.

Table 1.Finite element analysis object

\begin{tabular}{ccc}
\hline \multirow{2}{*}{ Specimen } & \multicolumn{2}{c}{ Parameter } \\
\cline { 2 - 3 } & reinforcement & Section size(mm) \\
\hline $4-1$ & $\mathrm{X}$ & - \\
$4-2$ & $\mathrm{O}$ & $157.06 * 110 * 55 * 55$ \\
$4-3$ & $\mathrm{O}$ & $135.84 * 110 * 55 * 55$ \\
\hline
\end{tabular}

\subsection{Analysis result}

\section{(1) Specimen 4-1}

In case of specimen 4-1, since T-shaped stiffener was not reinforced, resistance was only caused by out-of-plane deformation of steel pipe. Since displacement was controlled to $500 \mathrm{~mm}$, load continued to increase, but yield of beam flange could not be reached. Fig. 9 shows analysis result of specimen 4-1.

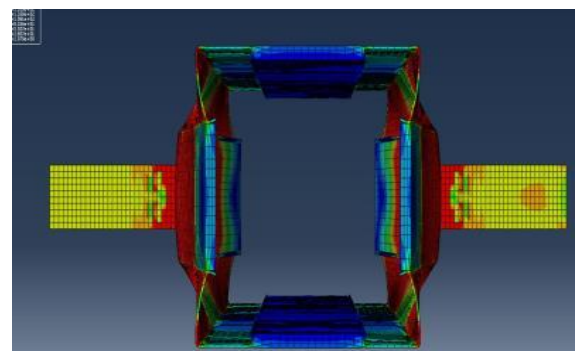

Fig. 9. Result of specimen 4-1

\section{(2) Specimen 4-2}

In case of specimen 4-2, T-shaped stiffener was reinforced. In the beginning, tensile force was transferred to T-shaped stiffener. After Tshaped stiffener yielded, out-of-plane deformation of steel pipe began to appear distinctly. Yield strength of T-shaped stiffener and resistance of out-of-plane deformation of steel pipe are larger than beam flange yield strength, resulting in beam flange yielding. Fig. 10 and 11 show yield and analysis result of specimen 4-2. 


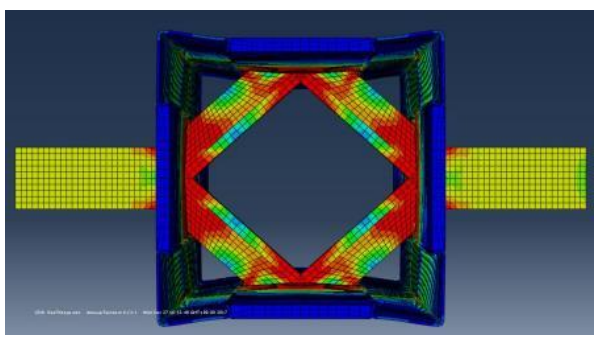

Fig. 10.Yield of specimen 4-2 T-shaped stiffener

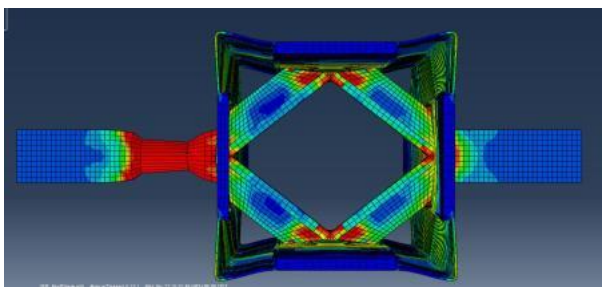

Fig. 11. Result of specimen 4-2

(3) Specimen 4-3

Specimen 4-3 showed same behavior as specimen 4-2, and yield strength of T-shaped stiffener was less than specimen 4-2 because width of T-shaped stiffener horizontal member was narrow. Fig. 12 and 13 show yield and analysis result of specimen 4-3.

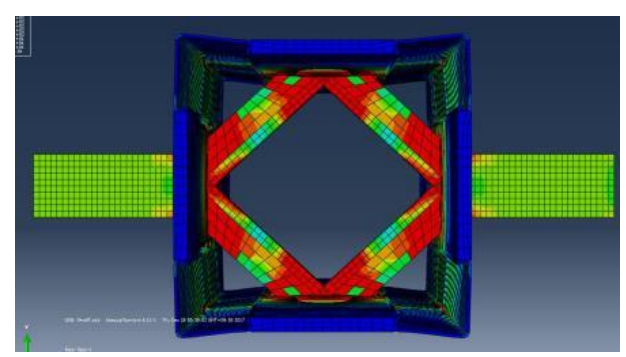

Fig. 12.Yield of specimen 4-3 T-shaped stiffener

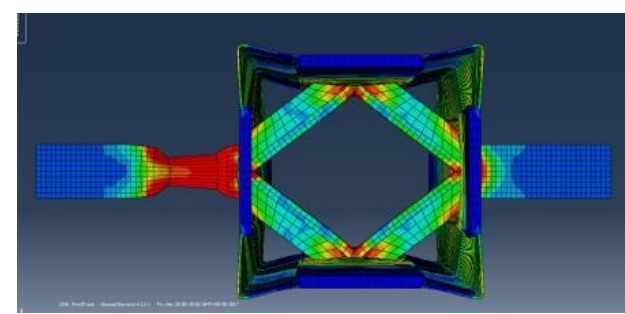

Fig. 13. Result of specimen 4-3

\subsection{Analysis and discussion}

Fig. 14. shows load-displacement relation for each specimen, and Table 2 shows T-shaped stiffener yield strength, beam flange yield strength and maximum load.

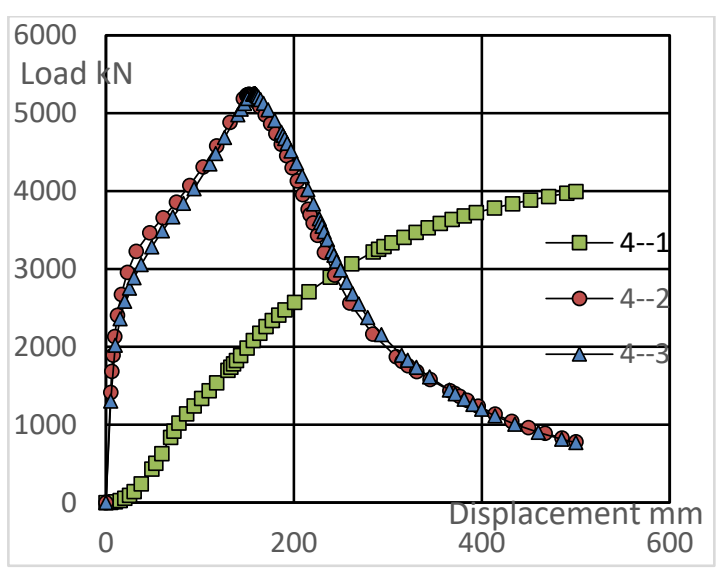

Fig. 14.Load-Displacement graph

Table 2.Result of finite element analysis

\begin{tabular}{cccc}
\hline Specimen & $\begin{array}{c}\text { T-shaped } \\
\text { stiffener } \\
\text { yield } \\
\text { strength }\end{array}$ & $\begin{array}{c}\text { Beam } \\
\text { flange } \\
\text { yield } \\
\text { strength }\end{array}$ & $\begin{array}{c}\text { Maximum } \\
\text { load }\end{array}$ \\
\hline $4-1$ & - & - & $3992.9 \mathrm{kN}$ \\
$4-2$ & $3856.92 \mathrm{kN}$ & $5240 \mathrm{kN}$ & $5240 \mathrm{kN}$ \\
$4-3$ & $3487.96 \mathrm{kN}$ & $5250.1 \mathrm{kN}$ & $5250.1 \mathrm{kN}$ \\
\hline
\end{tabular}

Yield strength of beam flange used in analysis is $5362.5 \mathrm{kN}$ by formula. Value according to T-shaped stiffener yield strength formula is $3970.33 \mathrm{kN}$ for specimen 4-2 and $3433.91 \mathrm{kN}$ for specimen 4-3. Table 3 and Table 4 compares analytical value with formula value.

Table 3.Comparison of T-shaped stiffener

\begin{tabular}{cccc}
\hline Specimen & $\begin{array}{c}\text { Analytical } \\
\text { value }\end{array}$ & $\begin{array}{c}\text { Formula } \\
\text { value }\end{array}$ & $\begin{array}{c}\text { Formula / } \\
\text { Analysis }\end{array}$ \\
\hline $4-2$ & $3856.92 \mathrm{kN}$ & $3970.33 \mathrm{kN}$ & 1.029 \\
$4-3$ & $3487.96 \mathrm{kN}$ & $3433.91 \mathrm{kN}$ & 0.985 \\
\hline
\end{tabular}

Table 4.Comparison of beam flange

\begin{tabular}{cccc}
\hline Specimen & $\begin{array}{c}\text { Analytical } \\
\text { value }\end{array}$ & $\begin{array}{c}\text { Formula } \\
\text { value }\end{array}$ & $\begin{array}{c}\text { Formula / } \\
\text { Analysis }\end{array}$ \\
\hline $4-2$ & $5240 \mathrm{kN}$ & $5362.5 \mathrm{kN}$ & 1.023 \\
$4-3$ & $5250.1 \mathrm{kN}$ & $5362.5 \mathrm{kN}$ & 1.021 \\
\hline
\end{tabular}

Yield strength of T-shaped stiffener and beam flange were compared with analytical value and formula value, respectively. As a result, in case of specimen 4-2, difference was $2.9 \%$ for $\mathrm{T}$-shaped stiffener and $2.3 \%$ for beam flange. In case of specimen 4-3, difference was $1.5 \%$ for $\mathrm{T}$-shaped stiffener and $2.1 \%$ for beam flange. 


\section{Tensile experiment of column-beam connection to confirm behavior of concrete and $\mathrm{T}$-shaped stiffener}

\subsection{Plan of experiment}

Columns of specimens used for columnbeam connection tensile experiment were divided into three types according to width. Beam flange is divided into two types according to thickness, and T-shaped stiffener is divided into three types according to size. There are 5 types of experiment specimen, all using SM490. Unlike analysis, all experiments were charged with concrete and concrete strength was planned to be $24 \mathrm{MPa}$. Experiment was applied tensile force on both sides of beam flange using $3000 \mathrm{kN}$ hydraulic universal testing machine(U.T.M). Load was applied to displacement control with $0.02 \mathrm{~mm} / \mathrm{s}$ of force speed until failure mode was confirmed after maximum load. Table 5 and Fig. 15 show specimen of Tensile experiment.

Table 5.List of experiment specimen

\begin{tabular}{cccc}
\hline Specimen & $\begin{array}{c}\text { Width } \\
\text { of } \\
\text { Column }\end{array}$ & $\begin{array}{c}\text { Beam } \\
\text { flange }\end{array}$ & $\begin{array}{c}\text { T-shaped } \\
\text { stiffener }\end{array}$ \\
\hline $5-1$ & $500 \mathrm{~mm}$ & $150 * 14$ & $106.07 * 28 * 14 * 14$ \\
$5-2$ & $500 \mathrm{~mm}$ & $150 * 10$ & $106.065 * 20 * 10 * 10$ \\
$5-3$ & $500 \mathrm{~mm}$ & $150 * 10$ & $80 * 20 * 10 * 10$ \\
$5-4$ & $650 \mathrm{~mm}$ & $150 * 14$ & $106.07 * 28 * 14 * 14$ \\
$5-5$ & $800 \mathrm{~mm}$ & $150 * 14$ & $106.07 * 28 * 14 * 14$ \\
\hline
\end{tabular}

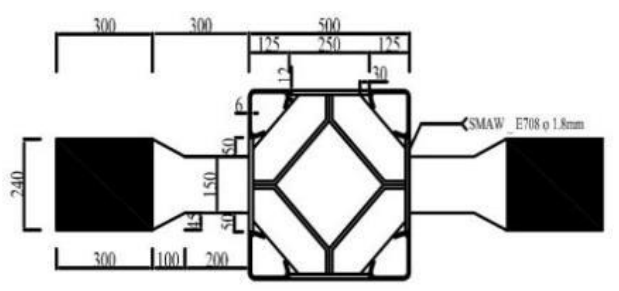

Fig. 15.Details of 500mm cross section

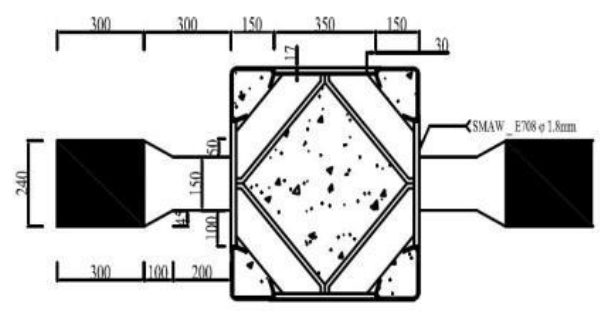

Fig. 16.Details of $650 \mathrm{~mm}$ cross section

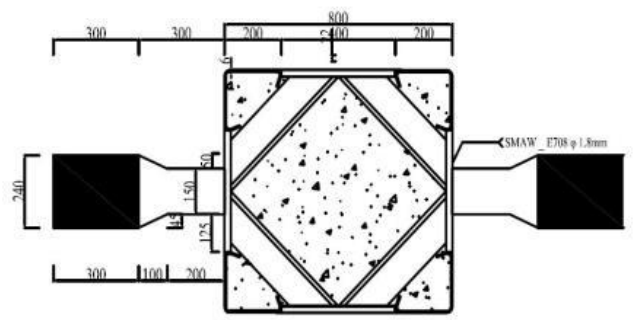

Fig. 17.Details of $800 \mathrm{~mm}$ cross section

\subsection{Result of experiment}

(1) Result of material test

In order to investigate mechanical properties of steel used in this experiment, three tensile test specimens were cut and tested in accordance with KS B 0801 and 0802 standards. Material used is SM490 $10 \mathrm{~mm}, 14 \mathrm{~mm}$ steel. Results of each test specimen are shown in Table 6. In addition, concrete specimens were subjected to 21 day compressive strength test, and test results are shown in Table 7.

Table 6.Result of tensile test

\begin{tabular}{cccc}
\hline $\begin{array}{c}\text { Steel } \\
\text { grade }\end{array}$ & Thickness & $\begin{array}{c}\text { Yield } \\
\text { strength }\end{array}$ & $\begin{array}{c}\text { Tensile } \\
\text { strength }\end{array}$ \\
\hline \multirow{2}{*}{ SM490 } & $10 \mathrm{~mm}$ & $450 \mathrm{MPa}$ & $536 \mathrm{MPa}$ \\
& $14 \mathrm{~mm}$ & $366 \mathrm{MPa}$ & $478 \mathrm{MPa}$ \\
\hline
\end{tabular}

Table 7.Result of concrete compressive strength test

\begin{tabular}{ccc}
\hline $\begin{array}{c}\text { Design } \\
\text { Strength }\end{array}$ & Size & Test Result \\
\hline $24 \mathrm{MPa}$ & $\Phi 100 \times 200$ & $27 \mathrm{MPa}$ \\
\hline
\end{tabular}

(2) Result of connection tensile experiment

Table 8 shows results of connection tensile experiment, and Fig. 18 shows failure mode of each specimen.

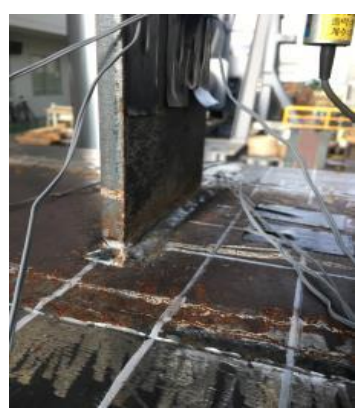

(a)Specimen 5-1

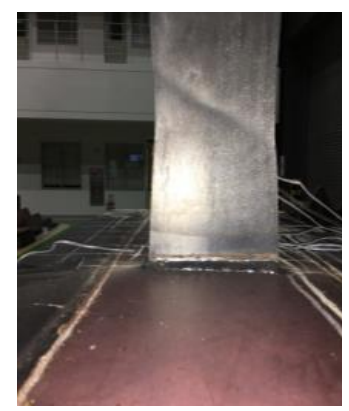

(b)Specimen 5-2 


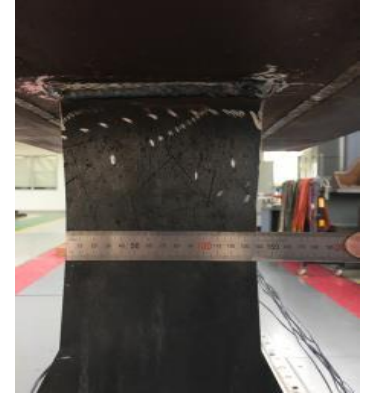

(c)Specimen 5-3

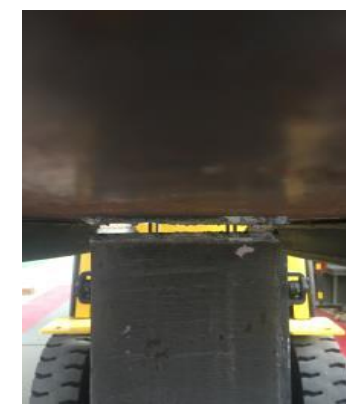

(d)Specimen 5-4

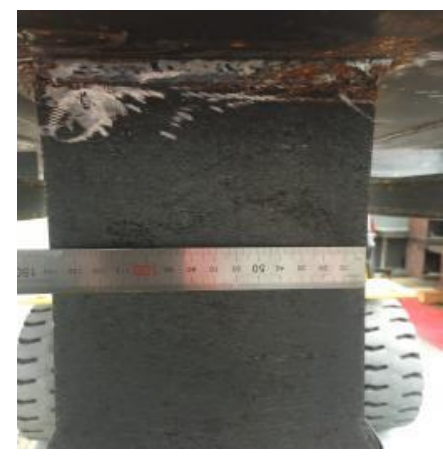

(e)Specimen 5-5

Fig. 18.Failure mode of each specimen

Table 8.Result of tensile experiment

\begin{tabular}{cccc}
\hline Specimen & $\begin{array}{c}\text { Yield } \\
\text { load }\end{array}$ & $\begin{array}{c}\text { Maximum } \\
\text { load }\end{array}$ & $\begin{array}{c}\text { Expected } \\
\text { load }\end{array}$ \\
\hline $5-1$ & $760 \mathrm{kN}$ & $952 \mathrm{kN}$ & $769 \mathrm{kN}$ \\
$5-2$ & $667 \mathrm{kN}$ & $786 \mathrm{kN}$ & $675 \mathrm{kN}$ \\
$5-3$ & $701 \mathrm{kN}$ & $799 \mathrm{kN}$ & $675 \mathrm{kN}$ \\
$5-4$ & $771 \mathrm{kN}$ & $1029 \mathrm{kN}$ & $769 \mathrm{kN}$ \\
$5-5$ & $771 \mathrm{kN}$ & $1069 \mathrm{kN}$ & $769 \mathrm{kN}$ \\
\hline
\end{tabular}

Expected load is value obtained by multiplying cross sectional area of beam flange by material test result, respectively. Yield load of experiment was within 3\% error of expected load. Failure mode was observed at weld zone of beam flange-column steel pipe at specimen 5-1 and 5-4. Specimen 5-2, 5-3, 5-5 showed beam flange necking. Load-Displacement graph for each specimen is shown in Fig. 19 and 20.

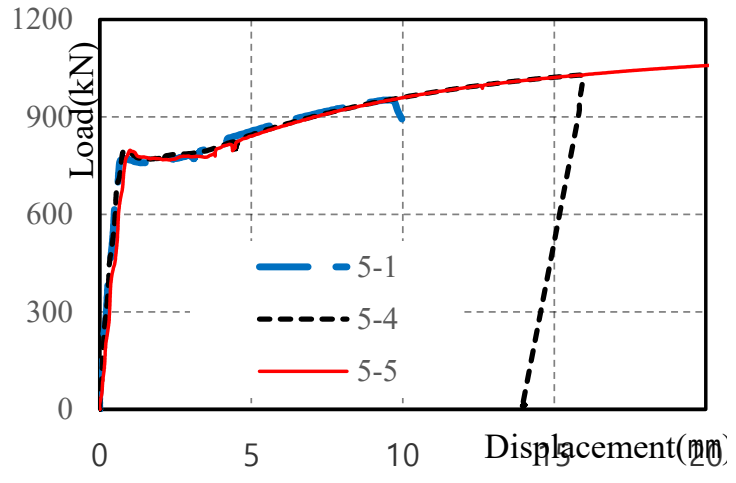

Fig. 19.Load-Displacement graph for specimen with flange $14 \mathrm{~mm}$

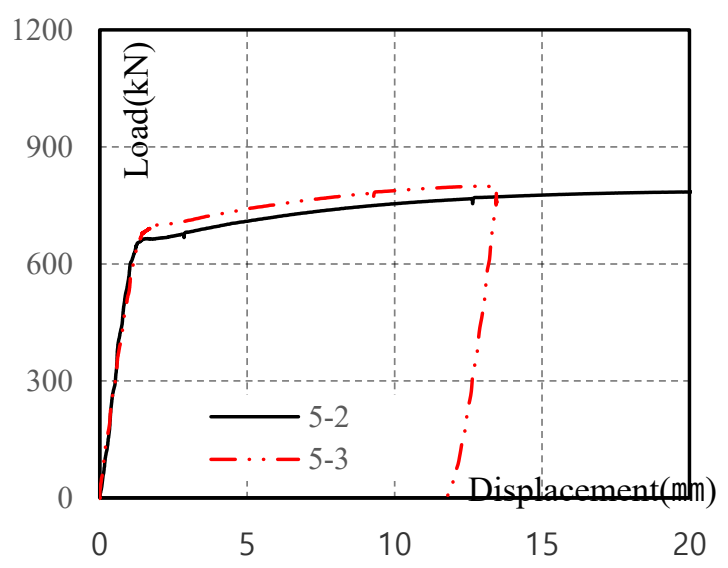

Fig. 20.Load-Displacement graph for specimen with flange $10 \mathrm{~mm}$

\subsection{Analysis and discussion}

T-shaped stiffener and concrete behave together from the moment tensile force acts. Therefore, it is considered that tensile strength to resist is different according to yield strength of T-shaped stiffener and ratio of strength due to concrete cone failure. Table 9 shows yield strength of $\mathrm{T}$-shaped stiffener and cone failure and ratio between two by strength formula. Fig. 21, 22 and Table 10 show strain distribution and analysis for each load step of experiment specimen.

Table 9. Value by strength formula

\begin{tabular}{cccc}
\hline Specimen & $\begin{array}{c}\text { T-shaped } \\
\text { stiffener } \\
\text { yield } \\
\text { strength }\end{array}$ & $\begin{array}{c}\text { Concrete } \\
\text { cone } \\
\text { failure }\end{array}$ & $\begin{array}{c}\text { T-shaped stiffener } \\
\text { / Cone failure }\end{array}$ \\
\hline $5-1$ & $768.6 \mathrm{kN}$ & $288.84 \mathrm{kN}$ & 2.66 \\
$5-2$ & $675 \mathrm{kN}$ & $294.95 \mathrm{kN}$ & 2.29 \\
$5-3$ & $509.1 \mathrm{kN}$ & $283.49 \mathrm{kN}$ & 1.8 \\
$5-4$ & $768.6 \mathrm{kN}$ & $483.28 \mathrm{kN}$ & 1.59 \\
$5-5$ & $768.6 \mathrm{kN}$ & $795.08 \mathrm{kN}$ & 0.97 \\
\hline
\end{tabular}




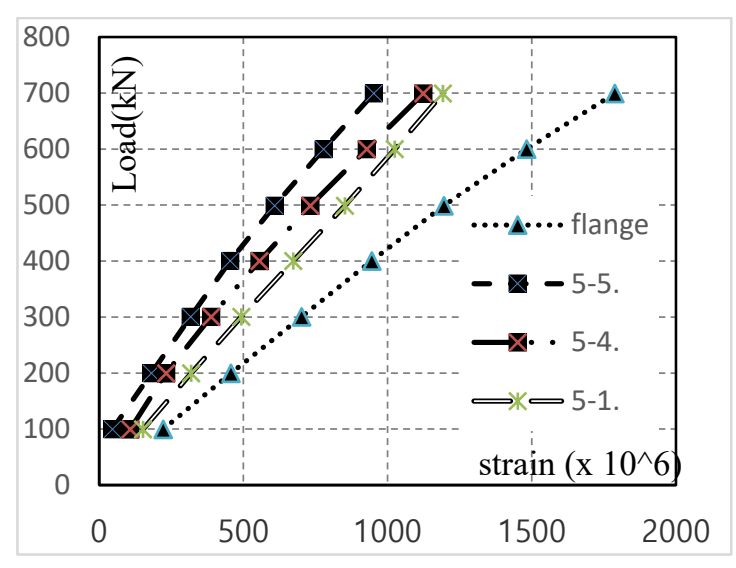

Fig. 21.Strain distribution by step of load for specimen with flange $14 \mathrm{~mm}$

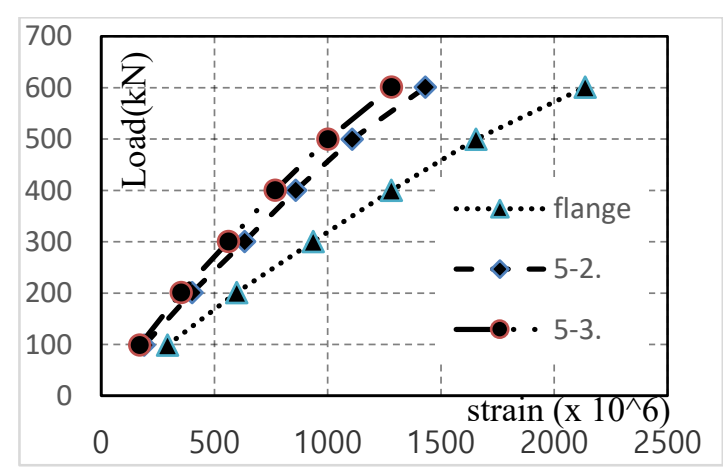

Fig. 22.Strain distribution by step of load for specimen with flange $10 \mathrm{~mm}$

Table 10. Ratio of T-shaped stiffener to cone failure

\begin{tabular}{cccc}
\hline Specimen & $\begin{array}{c}\text { Experiment } \\
\text { value }\end{array}$ & $\begin{array}{c}\text { Formula } \\
\text { value }\end{array}$ & $\begin{array}{c}\text { Formula / } \\
\text { Experiment }\end{array}$ \\
\hline $5-1$ & 2.16 & 2.66 & 1.23 \\
$5-2$ & 2.03 & 2.29 & 1.13 \\
$5-3$ & 1.5 & 1.8 & 1.2 \\
$5-4$ & 1.63 & 1.59 & 0.98 \\
$5-5$ & 1.04 & 0.97 & 0.93 \\
\hline
\end{tabular}

As a result of comparing experimental value with formula value of ratio of T-shaped stiffener to cone failure in elastic range of beam flange, error of 5-1 specimen was $23 \%$ and the others were $13 \%, 20 \%, 2 \%$, and $7 \%$, respectively.

\section{Conclusion}

In this study, to develop shape and to propose strength formula of composite mega column to beam connection, finite element analysis and connection tensile experiment were carried out. Through finite element analysis, load transfer mechanism through $\mathrm{T}$-shaped stiffener in concrete non-charging steel pipe was confirmed and yield strength formula was verified. In addition, when $\mathrm{T}$-shaped stiffener and concrete acted as composite section, through connection tensile experiment, load transfer mechanism and failure mode were confirmed. Conclusions of this study are as follows.

(1) Yield strength of T-shaped stiffener is determined by cross sectional area of horizontal member, and concrete cone failure is determined by area and height of T-shaped stiffener and column section size.

(2) Yield strength of composite mega column connection is determined by yield strength of Tshaped stiffener and concrete cone failure. In elastic range, tensile force resists according to ratio of T-shaped stiffener to cone failure. In other words, strength of connection is thought that large value of dominant $\mathrm{T}$-shaped stiffener and cone failure.

(3) Strength formula verified by finite element analysis and tensile experiment of connection are as follows.

$$
\begin{aligned}
P_{s}= & b_{s} \times t_{s h} \times f_{y s} \times 2 \times \cos \theta \\
P_{c 1}= & 2 \times\left[\left(\left(\sqrt{2} b_{s}+b_{a}\right) \times b_{t}\right)+\left(\sqrt{2} b_{s} \times\right.\right. \\
& \left.\left.\left(\frac{b_{c}}{2}-t_{s v}-b_{a}-b_{t}\right)\right)\right] \times v_{c}
\end{aligned}
$$

$$
\begin{aligned}
& P_{c 2}=2 f_{t}\left(h_{c}+h_{s}-2 t_{s h}\right) \times\left(\frac{b_{c}}{2}-t_{s v}\right) \\
& P_{c 1}+P_{c 2}=P_{c}
\end{aligned}
$$

\section{References}

[1] Lee SH. Behavior of welded built-up square CFT. PhD thesis; 2008.

[2] Joo JS, Song JW, Park DS, Yom KS, Choi SM. A study on the tensile strength of built-up column-beam connections for composite mega column with 1 meter width. Proceeding of Annual Conference of the Architectural Institute of Korea 2016;36(2):732-733.

[3] Lee SJ, Jeon BH, Lee KH, Jung JA, Choi SM. A suggestion of tensile strength formulae of cold formed square CFT column-to-beam connections with internal diaphragm. Proceeding of Annual Conference of the Architectural Institute of Korea 2007;27(1):65-68. 
[4] Lee KH, Lee IH, Won YA, Kim KS, Choi SM. A suggestion of tensile strength formula for an anchored type connection with internal vertical plates for cold-formed square CFT column. Proceeding of Annual Conference of the Architectural Institute of Korea 2007;27(1):6164.

[5] Kim SH, Choi SM. Tensile strength and concrete cone failure in CFT connection with internal diaphragms. International Journal of Steel Structures 2017;17(2):643-652. 